Keywords: prostate cancer; metabolomic profiling; aggressive; pre-diagnosed serum; pyroglutamine; gamma-glutamyl peptides; $\mathrm{N}$-acetyl amino acids; fatty acids

\title{
Serum metabolomic profiling of prostate cancer risk in the prostate, lung, colorectal, and ovarian cancer screening trial
}

\author{
Jiaqi Huang ${ }^{1,4}$, Alison M Mondul ${ }^{2,4}$, Stephanie J Weinstein ${ }^{1}$, Stella Koutros ${ }^{1}$, Andriy Derkach ${ }^{1}$, Edward Karoly ${ }^{3}$, \\ Joshua N Sampson ${ }^{1}$, Steven C Moore ${ }^{1}$, Sonja I Berndt ${ }^{1}$ and Demetrius Albanes ${ }^{\star 1}$ \\ ${ }^{1}$ Division of Cancer Epidemiology and Genetics, National Cancer Institute, NIH, Department of Health and Human Services, \\ Bethesda, MD, USA; ${ }^{2}$ Department of Epidemiology, University of Michigan School of Public Health, Ann Arbor, MI, USA and \\ ${ }^{3}$ Metabolon, Inc., Morrisville, NC, USA
}

Background: Two recent metabolomic analyses found serum lipid, energy, and other metabolites related to aggressive prostate cancer risk up to 20 years prior to diagnosis.

Methods: We conducted a serum metabolomic investigation of prostate cancer risk in the Prostate, Lung, Colorectal, and Ovarian Cancer Screening Trial that included annual serum total prostate-specific antigen measurement and digital rectal examination. This nested study included 380 cases diagnosed post-screening and 380 controls individually matched to cases on age, race, study centre, and blood-collection date (median time to diagnosis, 10 years (range 4.4-17 years)). Sera were analysed on a highresolution accurate mass platform of ultrahigh-performance liquid and gas chromatography/mass spectroscopy that identified 695 known metabolites. Logistic regression conditioned on the matching factors estimated odds ratios (OR) and $95 \%$ confidence intervals of risk associated with an 80th percentile increase in the log-metabolite signal.

Results: Twenty-seven metabolites were associated with prostate cancer at $P<0.05$. Pyroglutamine, gamma-glutamylphenylalanine, phenylpyruvate, $\mathrm{N}$-acetylcitrulline, and stearoylcarnitine showed the strongest metabolite-risk signals $(\mathrm{ORs}=0.53,0.51$, $0.46,0.58$, and 1.74 , respectively; $0.001 \leqslant P \leqslant 0.006$ ). Findings were similar for aggressive disease (peptide chemical class, $P=0.03$ ). None of the P-values were below the threshold of Bonferroni correction, however.

Conclusions: A unique metabolomic profile associated with post-screening prostate cancer is identified that differs from that in a previously studied, unscreened population.

Prostate cancer is the most frequently diagnosed malignancy and the third leading cause of cancer mortality after lung and colorectal cancer among men in developed populations (Torre et al, 2015). Its aetiology remains largely unknown, with few established risk factors, other than age, race, family history of prostate cancer, and a number of low-penetrance genetic variants (Bostwick et al, 2004; Chan et al, 2005; Wolk, 2005; Kote-Jarai et al, 2011; Barbieri et al, 2012; Allott et al, 2013). Recent advances in liquid or gas chromatography, mass spectrometry, and nuclear magnetic resonance methods have facilitated measurement of hundreds or thousands of low molecular weight, $80-1000 \mathrm{Da}$ metabolites in biological samples such as serum, urine, and tissue. Measurement of the metabolome provides an integrated assessment of exogenous and endogenous exposures, and the host response to them, and has the potential to elucidate novel disease associations and biological mechanisms.

*Correspondence: Dr D Albanes; E-mail: daa@nih.gov

${ }^{4}$ These authors contributed equally to this work.

Received 5 July 2016; revised 16 August 2016; accepted 24 August 2016; published online 27 September 2016 
Two recent studies (Mondul et al, 2014, 2015) in the Alpha-Tocopherol, Beta-Carotene Cancer Prevention (ATBC) cohort identified metabolites related to aggressive prostate cancer in sera collected two decades prior to diagnosis. Lipid and energy metabolites including alpha-ketoglutarate (AKG), citrate, inositol-1-phosphate, several glycerophospholipids, and fatty acids, were lower in aggressive cases than in controls (Mondul et al, 2015). The present investigation examines the prospective metabolomic profile of prostate cancer risk in a case-control study nested within the Prostate, Lung, Colorectal, and Ovarian Cancer Screening (PLCO) Trial.

\section{MATERIALS AND METHODS}

Study population. The PLCO trial was a large randomisedcontrolled trial designed to evaluate the efficacy of screening methods for prostate, lung, colorectal, or ovarian cancer. Participants without a history of these malignancies, ages 55 to 74 years, were enroled from 10 centres in the USA between 1993 and 2001, and were randomly assigned to either the screening or non-screening arm (Gohagan et al, 2000; Prorok et al, 2000; Hayes et al, 2005). Blood samples were collected from participants in the screening arm only, between 0700 hours and 1600 hours without regard to the fasting status, and were aliquoted within $2 \mathrm{~h}$ and stored at $-70^{\circ} \mathrm{C}$. The cancer screenings included chest $\mathrm{x}$-ray, flexible sigmoidoscopy, and annual serum total prostate-specific antigen (PSA) measurement (for 6 years) and digital rectal examination (DRE; for 4 years). Men with an elevated PSA of $\geqslant 4 \mathrm{ng} \mathrm{ml}^{-1}$ or a DRE suspicious for prostate cancer were referred to their medical-care providers for further prostate cancer workup. Information for prostate cancer diagnoses based on abnormal screening results was retrieved from medical and pathology records. Additional prostate cancer diagnoses, including postscreening trial cases were identified through annual self-reported questionnaire responses and through the National Death Index, followed by medical record review and confirmation. All men ( $n=28243$ ) were followed from their initial prostate cancer screen, to the date of prostate cancer diagnosis, date of death (National Death Index), censor date (26 April 2012), or loss to follow-up, whichever occurred first.

Participants completed self-administered questionnaires at enrolment that included data regarding sociodemographics, height, weight, smoking behaviour, family history of cancer, and other diseases, physical activity, use of selected medications, and recent history of screening exams. All participants provided written informed consent, and the PLCO study was approved by the institutional review boards of the U.S. National Cancer Institute and the 10 PLCO screening centres.

Case identification and control selection. In order to increase time from blood collection to clinical diagnoses, 380 prostate cancer cases were randomly chosen from participants diagnosed during the post-screening trial period (4.4-17.0 years after baseline). On the basis of previous study findings (Mondul et al, 2014; 2015), aggressive cases were oversampled $(n=298)$ and defined as those diagnosed with stage III or IV based on the tumour-node-metastasis staging system (Fleming et al, 1997), or a biopsy Gleason score $\geqslant 8$. Cases with a Gleason score sum of 7 and stage II were considered to be of an intermediate level of aggressiveness $(n=82)$. Because baseline blood samples had been depleted by many previous prostate cancer studies, we analysed serum collected at the first or second screening year visit. Using the method of incidence-density sampling without replacement, we randomly selected 380 controls that were free from any cancer at the time of case diagnosis, and individually matched them to cases by age (within 5 years), race, study centre, study year, and date (within 30 days) of blood collection.

Metabolite assays. Serum metabolomic profiling was conducted on a high-resolution accurate mass platform of ultrahighperformance liquid chromatography/mass spectroscopy and gas chromatograph/mass spectroscopy (GC-MS; Metabolon, Durham, NC, USA). Workflow including extraction of raw data, peakidentification, and quality control (QC) processed on the assay platform, has been described (Evans et al, 2009; Dehaven et al, 2010). Metabolon measured values for a total of 722 identified metabolites. We excluded 27 metabolites for which $>500$ participants (66\%) had missing values (below limit of detection), leaving 695 identified compounds for analysis. Metabolites were categorised as belonging to one of eight mutually exclusive chemical classes: amino acids and amino acid derivatives (subsequently referred to as 'amino acids'), carbohydrates, cofactors and vitamins, energy metabolites, lipids, nucleotides, peptides, or xenobiotics. Each batch included blinded quality control samples (9\%) from two male individuals. To assess the technical reliability of data, coefficients of variation $($ median $=0.2$, interquartile range $=0.12-0.32$ ), and intraclass correlation coefficients (median $=0.87$, interquartile range $=0.64-0.98$ ) were calculated as measures of QC. The cases and their matched controls were assayed within the same batches in order to avoid any effect of batch differences on the risk estimates.

Statistical analysis. Baseline characteristics of cases and controls were compared by either Wilcoxon rank sum or $\chi^{2}$-tests, for continuous or categorical variables, respectively. The signal of each metabolite was normalised within a given batch to standardise the batch variability, and for missing (below limit of detection) values, we imputed the minimum non-missing value. Metabolite values were log-transformed for analysis. Conditional logistic regression was used to examine odds ratios (ORs) and their 95\% confidence intervals (CI), for the association between prostate cancer and each log-metabolite signal with an 80th percentile increase. Only matching factors were included in the final models. In addition to the matching factors, we performed sensitivity analyses to include BMI $\left(<25 \mathrm{~kg} \mathrm{~m}^{-2}, 25-\right.$ $30 \mathrm{~kg} \mathrm{~m}^{-2}$, or $\geqslant 30 \mathrm{~kg} \mathrm{~m}^{-2}$ ) in the model, in addition to several other potential confounding factors. These included smoking status (never, former, or current), diabetes (yes or no), height $(<175 \mathrm{~cm}, 175-$ $180 \mathrm{~cm}$, or $\geqslant 180 \mathrm{~cm})$, physical activity $(<1 \mathrm{~h}$ per week, $1-3 \mathrm{~h}$ per week, or $\geqslant 4 \mathrm{~h}$ per week), alcohol consumption $(<0.05$ drinks per day, $0.05-1$ drinks per day, or $\geqslant 1$ drinks per day), processed meat consumption $(<6.6 \mathrm{~g}$ per day, 6.6-16.8 g per day, or $\geqslant 16.8 \mathrm{~g}$ per day), red meat consumption ( $<20.4 \mathrm{~g}$ per day, 20.4-43.7 g per day, or $\geqslant 43.7 \mathrm{~g}$ per day), and total fat intake ( $<60.3 \mathrm{~g}$ per day, $60.3-88 \mathrm{~g}$ per day, or $\geqslant 88 \mathrm{~g}$ per day). According to a Bonferroni correction for 695 tests, the threshold for statistical significance in our analysis is $P=0.000072$. However, this threshold is highly stringent due to the inter-correlations between many metabolites. We therefore also used principle component analysis (Jolliffe, 2005), and explored whether the grouped metabolites can distinguish case-control status. The top 10 principle components of metabolite measurements were calculated, and the same approach of conditional logistic regression (log-level with an 80th percentile increase) was applied to examine whether these components were associated with overall or aggressive prostate cancer. We also used a false-discovery rate (FDR) of $20 \%$ to define the significance threshold. We used gene-set analysis (GSA), a standard pathway analysis, to examine whether pre-defined metabolic super- and sub-pathways were associated with prostate cancer (Subramanian et al, 2005).

We performed additional analyses restricting to aggressive or non-aggressive cases, non-Hispanic white men, black men, and men of other races, and stratified by age at enrolment $(<65$ vs $65+$ years $)$ and follow-up time $(<10$ years, $\geqslant 10$ years $)$. The 
analysis by race was conducted, in part, for comparison with prior studies of Caucasian populations (Mondul et al, 2014, 2015).

Analyses were performed with SAS software version 9.3 (SAS Institute, Cary, NC, USA), and the GSA analysis was performed with the $\mathrm{R}$ statistical language version 3.2.3 (Vienna, Austria). All reported $P$-values are two-sided.

\section{RESULTS}

Median time from blood collection to prostate cancer diagnosis was 10 years (inter-decile range $=7.2-13.0$ years) and median age at diagnosis was 72 years. Compared with controls, cases were more likely to have higher serum PSA and a family history of prostate cancer, and were more physically active at age 40 years, but were similar with respect other characteristics at study baseline (Table 1).

Metabolites related to risk of overall, aggressive and nonaggressive prostate cancer with a nominal $P$-value of $<0.05$ are shown in Tables $2-4$ sorted by chemical class, sub-pathway and $P$ values. All metabolite associations with overall prostate cancer risk are presented in Supplementary Table 1 . None of the $P$-values were below the threshold of correction for multiple comparisons or with a FDR $<20 \%$. The amino acids pyroglutamine (pGLU), phenylpyruvate, and $\mathrm{N}$-acetylcitrulline, as well as the peptide gamma-glutamylphenylalanine, yielded the strongest signals, being inversely associated with overall prostate cancer $(0.001 \leqslant P<0.004$, Table 2), whereas the acylcarnitine metabolite stearoylcarnitine was positively associated $(\mathrm{OR}=1.74$, Table 2$)$. Findings were similar for aggressive disease, with the peptide class of compounds being inversely associated (Table $3, P=0.027$ ), but not with nonaggressive cancer. For non-aggressive disease, alpha-tocopherol, primary bile acid, and steroid hormone metabolites were wellrepresented and inversely associated with risk, as was cyclic AMP (Table 4). Stratification based on median time to diagnosis of aggressive disease revealed long-chain fatty acids, monohydroxy fatty acids, acylcarnitines, monoacylglycerol lipids, and lysolipids

\begin{tabular}{|c|c|c|c|}
\hline & Controls & Cases & $P$-value \\
\hline$N$ & 380 & 380 & \\
\hline Age at blood collection, years & 64 & 64 & Matched \\
\hline $\begin{array}{l}\text { Race, \% } \\
\text { White, non-Hispanic } \\
\text { Black } \\
\text { Other races }\end{array}$ & $\begin{array}{l}90.8 \\
4.5 \\
4.7\end{array}$ & $\begin{array}{l}90.8 \\
4.5 \\
4.7\end{array}$ & Matched \\
\hline PSA at blood draw $\left(\mathrm{ng} \mathrm{ml}^{-1}\right)$ & 1.4 & 2.1 & $<0.0001$ \\
\hline Height, cm & $178.4(2.7)$ & $178.0(2.6)$ & 0.371 \\
\hline Weight, kg & $87.0(14.3)$ & $87.0(13.7)$ & 0.930 \\
\hline $\mathrm{BMI}, \mathrm{kg} \mathrm{m}^{-2}$ & $27.4(4.0)$ & $27.5(4.1)$ & 0.659 \\
\hline $\begin{array}{l}\text { Tobacco smoking status, \% } \\
\text { Never smoker } \\
\text { Former smoker } \\
\text { Current smoker }\end{array}$ & $\begin{array}{c}37.9 \\
56.3 \\
5.8\end{array}$ & $\begin{array}{c}43.2 \\
52.4 \\
4.5\end{array}$ & 0.29 \\
\hline Tobacco smoking duration, $^{\mathbf{b}}$ years & $25.1(12.9)$ & $23.9(13.3)$ & 0.272 \\
\hline Family history of prostate cancer, \% & 3.6 & 5.4 & 0.073 \\
\hline Diabetes, \% & 6.1 & 7.1 & 0.56 \\
\hline $\begin{array}{l}\text { Physical activity at age } 40 \\
\text { (h per week), \% } \\
4+h(v s<3 \text { h) }\end{array}$ & 29.7 & 38.4 & 0.017 \\
\hline 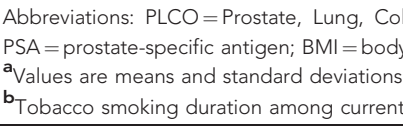 & $\begin{array}{l}\text { rectal, and Ova } \\
\text { mass index. } \\
\text { inless otherwise } \\
\text { or former smoke }\end{array}$ & $\begin{array}{l}\text { ian Cancer Scr } \\
\text { ndicated. }\end{array}$ & ening Trial; \\
\hline
\end{tabular}

being positively associated among cases diagnosed within 10 years, and citrate, sphingolipid, steroid hormone, and glutathione metabolites associated among cases diagnosed 10-20 years after blood collection (data not shown).

These findings were not materially changed when adjusted for BMI (Supplementary Table 2) or for BMI plus several additional factors including smoking status, diabetes, height, physical activity, alcohol consumption, processed and red meat consumption, and total fat intake (Supplementary Table 3). These findings were also not substantially altered when adjusted for serum total PSA (data not shown), and were essentially similar in non-Hispanic white, black, and other races combined groups, although with some differences in the latter two populations that are probably due to small sample sizes (Supplementary Tables 4-6). We found no material interactions between the top 27 metabolites and other risk factors, including age, BMI, and smoking (data not shown).

Although none of the top 10 principle components were significantly associated with overall or aggressive prostate cancer, with all tests having $P$-values $>0.025(P<0.005$ was the significant level), the metabolite sub-pathway analysis revealed that branched and medium-chain fatty acid metabolites, as well as the tocopherol metabolites, were inversely associated with overall prostate cancer $(P=0.016,0.032$, and 0.017 , respectively, Table 5). Aggressive disease was positively associated with the branched-chain fatty acids $P=0.015$ ), and inversely related to the tryptophan and urea cycle/arginine/proline metabolites $(P=0.037$ and 0.046 , respectively). The tocopherol and primary bile acid metabolite subclasses were inversely related to non-aggressive cancer $(P=0.014$ and 0.021 , respectively, Table 5).

Among the top metabolites related to prostate cancer in our earlier investigation (Mondul et al, 2015) that served as our a priori hypotheses for the present analysis, only three associations with overall prostate cancer replicated in the present data: the lipids 1-palmitoleoyl-2-linoleoyl-GPC $\quad(16: 1 / 18: 2) \quad(\mathrm{OR}=0.60$, 95\% CI $=0.40-0.88, \quad P=0.0096)$ and tauro-beta-muricholate $(\mathrm{OR}=0.68,95 \% \mathrm{CI}: 0.48-0.97, P=0.033)$, and the nucleotide 2 -deoxyuridine $\quad(\mathrm{OR}=1.47, \quad 95 \% \quad \mathrm{CI}: \quad 1.07-2.03, \quad P=0.019$; Table 2). By contrast, the inverse association between aggressive prostate cancer, and the energy metabolites, (Mondul et al, 2015) alpha-AKG or citrate, did not replicate, and appeared to have opposite associations (AKG $\mathrm{OR}=1.45, P=0.098$, and citrate $\mathrm{OR}=1.48, \quad P=0.077)$. It is noteworthy that these positive associations appeared stronger among cases diagnosed 10-20 years after blood collection (AKG OR $=1.83,95 \%$ CI 0.99-3.38, $P=0.053$; citrate $\mathrm{OR}=2.04,95 \%$ CI $1.06-3.91, \quad P=0.032)$ compared with those diagnosed within 10 years $(\mathrm{OR}=1.11$, $P=0.76$ for $\mathrm{AKG}$, and $\mathrm{OR}=1.13, P=0.68$ for citrate). The present data also did not replicate the previous positive associations with aggressive prostate cancer for phenylpyruvate, thyroxine, and arginine (Table 3 ), and trimethylamine- $N$-oxide (data not shown).

\section{DISCUSSION}

Top metabolite signals for overall prostate cancer risk observed here were pGLU, gamma-glutamylphenylalanine, phenylpyruvate, $\mathrm{N}$-acetylcitrulline, and stearoylcarnitine. Peptide metabolites were associated with aggressive disease, whereas most of the previously reported lipid and energy metabolites were not. These profiles appeared similar across racial/ethnic groups, although our sample size was small for non-white men. By contrast, risk of nonaggressive disease was related to tocopherols, sex steroids, and primary bile acids.

Pyroglutamine is a key amino acid residue for thyrotrophinreleasing hormone (TRH) and TRH-like peptides (Huber et al, 1998) that promote fertilisation by enhancing sperm capacitation (Cockle et al, 1994; Huber et al, 1998), act as paracrine factors 
Table 2. OR and $95 \% \mathrm{Cl}$ from conditional logistic regression of overall prostate cancer comparision of the 90 th and 10 th percentiles for serum metabolites $(\boldsymbol{P}<0.05)$ sorted by chemical class, sub-pathway, and $P$-value ${ }^{a, b}$

\begin{tabular}{|c|c|c|c|c|c|}
\hline Metabolite & Sub-pathway & OR & $95 \% \mathrm{Cl}$ & $P$-value & $\begin{array}{c}P \text {-value for } \\
\text { chemical class }\end{array}$ \\
\hline \multicolumn{5}{|l|}{ Amino acids and amino acids derivatives } & 0.20 \\
\hline Pyroglutamine & Glutamate metabolism & 0.53 & $0.36,0.78$ & 0.0013 & \\
\hline N-Acetylcitrulline & Urea cycle; arginine and proline metabolism & 0.58 & $0.41,0.84$ & 0.0034 & \\
\hline Homocitrulline & Urea cycle; arginine and proline metabolism & 0.69 & $0.47,1.00$ & 0.0480 & \\
\hline N-Acetylarginine & Urea cycle; arginine and proline metabolism & 0.69 & $0.48,1.00$ & 0.0490 & \\
\hline Tryptophan & Tryptophan metabolism & 0.72 & $0.51,1.00$ & 0.0490 & \\
\hline 5-Methylthioadenosine & Polyamine metabolism & 0.64 & $0.45,0.93$ & 0.0193 & \\
\hline Trans-urocanate & Histidine metabolism & 1.50 & $1.01,2.23$ & 0.0467 & \\
\hline \multicolumn{5}{|l|}{ Cofactors and vitamins } & 0.20 \\
\hline Gulonic acid & Ascorbate and aldarate metabolism & 0.73 & $0.56,0.96$ & 0.0239 & \\
\hline \multicolumn{5}{|l|}{ Energy } & 0.29 \\
\hline 15-Methylpalmitate & Fatty acid, branched & 1.63 & $1.12,2.38$ & 0.0112 & \\
\hline 17-Methylstearate & Fatty acid, branched & 1.47 & $1.03,2.11$ & 0.0354 & \\
\hline Hexadecanedioate & Fatty acid, dicarboxylate & 1.45 & $1.07,1.98$ & 0.0167 & \\
\hline Caproate (6:0) & Medium-chain fatty acid & 1.44 & $1.05,1.98$ & 0.0248 & \\
\hline 1-Palmitoleoyl-2-linoleoyl-GPC (16:1/18:2) & Phospholipid metabolism & 0.60 & $0.40,0.88$ & 0.0096 & \\
\hline 1-Palmitoyl-2-arachidonoyl-GPI (16:0/20:4) & Phospholipid metabolism & 1.64 & $1.09,2.47$ & 0.0187 & \\
\hline Trimethylamine- $\mathrm{N}$-oxide & Phospholipid metabolism & 0.68 & $0.47,0.97$ & 0.0327 & \\
\hline 1-Linoleoyl-2-arachidonoyl-GPC (18:2/20:4n6) & Phospholipid metabolism & 1.48 & $1.01,2.16$ & 0.0425 & \\
\hline Tauro-beta-muricholate & Primary bile acid metabolism & 0.68 & $0.48,0.97$ & 0.0329 & \\
\hline 1-Arachidonoyl-GPC (20:4n6) & Lysolipid & 1.46 & $1.01,2.10$ & 0.0457 & \\
\hline \multicolumn{5}{|l|}{ Nucleotide } & 0.61 \\
\hline 2'-Deoxyuridine & Pyrimidine metabolism & 1.47 & $1.07,2.03$ & 0.0191 & \\
\hline
\end{tabular}

influencing prostate cell growth and differentiation (Bilek et al, 1992), and stimulate thyroid hormone secretion (Bilek et al, 1991; Bilek, 2000; Maran et al, 2001). Gamma-glutamylphenylalanine and gamma-glutamylglycine peptides were also inversely associated with aggressive prostate cancer, similar to the gammaglutamylhistidine finding in the ATBC Study (Mondul et al, 2015). These metabolites are glutathione (GSH) degradation products of gamma-glutamyl transpeptidase activity (Zhang et al, 2005) that regenerates intracellular GSH (Wu et al, 2004; Zhang et al, 2005) for detoxification of reactive oxygen species (Wu et al, 2004; Maher, 2005; Zhang et al, 2005). Several $N$-acetyl amino acids including $\mathrm{N}$-acetylcitrulline, $\mathrm{N}$-acetylarginine, $\mathrm{N}$-acetyltryptophan, and $N$-acetylkynurenine were also reduced in men later diagnosed with prostate cancer, possibly indicating increased post-translational protein $N$-terminal acetylation (Aksnes et al, 2015) and aminoacetylase activity, the latter having been related to increased cell proliferation and carcinogenesis (Aksnes et al, 2015), and histone-chromatin gene regulation (Eberharter and Becker, 2002). Also inversely associated were tryptophan metabolites that influence the role of inflammation in cancer progression (Prendergast et al, 2014; Santhanam et al, 2016). Tryptophan and kynurenine pathway metabolites have been previously associated with several, particularly gastrointestinal, cancers (Uyttenhove et al, 2003; Witkiewicz et al, 2008; Liu et al, 2009; Koblish et al, 2010; Balachandran et al, 2011; Zhang et al, 2011a; 2011b; Ferdinande et al, 2012; Zhang et al, 2013).
The proliferative anabolic state of prostate adenocarcinomas requires active biosynthesis of amino acids, nucleic acids, peptides, and lipids (Gang et al, 2016), with dynamic metabolomic phenotype stages being likely. Aberrations in lipid metabolites and especially fatty acid metabolism have been extensively studied with respect to prostate carcinogenesis (Harvei et al, 1997; Norrish et al, 1999; Mannisto et al, 2003; Chavarro et al, 2007; Crowe et al, 2008; Bassett et al, 2013; Crowe et al, 2014; Wu et al, 2014). De novo fatty acid biosynthesis is upregulated in aggressive cancers (Nomura et al, 2010, 2011; Carracedo et al, 2013), and the present data appear consistent with this only with respect to branchedchain fatty acids. The lower serum lipid metabolomic profile previously demonstrated for aggressive prostate cancer risk encompassed not only fatty acids, presumably to provide energy for cell proliferation and tumour growth, but also a large number of lysolipids, inositols, and sphingomyelins that implicated cell membrane biosynthesis and signalling (Kuemmerle et al, 2011). Fatty acids rather than the latter compounds were more prominent in the present study and positively associated with risk, possibly indicating triglyceride mobilisation from adipose tissue and increased fatty acid synthase activity leading to increased acylcarnitine-mediated long-chain fatty acid transport into the mitochondria matrix for $\beta$-oxidation and ATP synthesis (Carter et al, 1995; Crowe et al, 2008). Despite laboratory evidence that eicosapentaenoic acid can inhibit prostate tumourigenesis (Cave, 1991; Rose, 1997; Astorg, 2004; Larsson et al, 2004; 
Table 3. OR and $95 \% \mathrm{Cl}$ from conditional logistic regression of aggressive prostate cancer comparision of the 90 th and 10 th percentiles for serum metabolites $(P<0.05)$ sorted by chemical class, sub-pathway, and $P$-value $e^{a, b}$

\begin{tabular}{|c|c|c|c|c|c|}
\hline Metabolite & Sub-pathway & OR & $95 \% \mathrm{Cl}$ & $P$-value & $\begin{array}{c}P \text {-value for } \\
\text { chemical class }\end{array}$ \\
\hline \multicolumn{5}{|l|}{ Amino acids and amino acids derivatives } & 0.17 \\
\hline Pyroglutamine & Glutamate metabolism & 0.48 & $0.31,0.74$ & 0.0011 & \\
\hline Thyroxine & Phenylalanine and tyrosine metabolism & 0.70 & $0.50,0.99$ & 0.0423 & \\
\hline Tryptophan & Tryptophan metabolism & 0.61 & $0.41,0.90$ & 0.0124 & \\
\hline N-Acetylkynurenine & Tryptophan metabolism & 0.55 & $0.34,0.88$ & 0.0137 & \\
\hline N-Acetylcitrulline & Urea cycle; arginine and proline metabolism & 0.62 & $0.41,0.92$ & 0.0182 & \\
\hline Arginine & Urea cycle; arginine and proline metabolism & 0.63 & $0.42,0.96$ & 0.0308 & \\
\hline N-Acetylarginine & Urea cycle; arginine and proline metabolism & 0.64 & $0.42,0.98$ & 0.0389 & \\
\hline 5-Methylthioadenosine & Polyamine metabolism & 0.63 & $0.41,0.96$ & 0.0308 & \\
\hline Trans-urocanate & Histidine metabolism & 1.63 & $1.02,2.60$ & 0.0410 & \\
\hline \multicolumn{5}{|l|}{ Lipids } & 0.17 \\
\hline 17-Methylstearate & Fatty acid, branched & 1.62 & $1.07,2.44$ & 0.0225 & \\
\hline 5Alpha-pregnan-3beta,20beta-diol monosulfate & Steroid & 1.57 & $1.04,2.37$ & 0.0330 & \\
\hline 1-Oleoylglycerol (18:1) & Monoacylglycerol & 1.58 & $1.03,2.43$ & 0.0375 & \\
\hline 1-Palmitoyl-2-arachidonoyl-GPI (16:0/20:4) & Phospholipid metabolism & 1.65 & $1.03,2.63$ & 0.0376 & \\
\hline 1-Stearoyl-2-oleoyl-GPC (18:0/18:1) & Phospholipid metabolism & 1.57 & $1.00,2.45$ & 0.0496 & \\
\hline Eicosapentaenoate $(20: 5 n 3)$ & Polyunsaturated fatty acid (n3 and n6) & 1.53 & $1.02,2.30$ & 0.0392 & \\
\hline \multicolumn{5}{|l|}{ Nucleotide } & 0.81 \\
\hline 2'-Deoxyuridine & Pyrimidine metabolism & 1.50 & $1.05,2.15$ & 0.0267 & \\
\hline \multicolumn{5}{|l|}{ Peptides } & 0.027 \\
\hline Leucylglutamine & Dipeptide & 0.58 & $0.38,0.88$ & 0.0098 & \\
\hline Gamma-glutamylphenylalanine & Gamma-glutamyl amino acid & 0.57 & $0.36,0.90$ & 0.0152 & \\
\hline Gamma-glutamylglycine & Gamma-glutamyl amino acid & 0.64 & $0.42,0.99$ & 0.0430 & \\
\hline
\end{tabular}

Kobayashi et al, 2006), we found this omega-3 fatty acid to be related to higher risk of aggressive prostate cancer, which is consistent with two studies (Crowe et al, 2008, 2014).

Our findings regarding non-aggressive prostate cancer are also of interest and differ substantially from those for aggressive disease. Notably, we detected an inverse risk association signal for alpha-tocopherol metabolites, consistent with both significantly lower prostate cancer incidence in one low-dose trial (Heinonen et al, 1998) and a recent pooled analysis of 15 international cohorts (Key et al, 2015). Several sex steroids also showed inverse risk associations with non-aggressive prostate cancer, including androgen precursors (e.g., DHEA-sulfate) and metabolites (e.g., 4-androstene-3beta, 17 diol-sulfate). (Testosterone was also inversely associated, but more weakly $(\mathrm{OR}=0.76$; $P=0.11)$ ). By contrast, only one sex steroid was related to aggressive disease and in a positive direction, more in line with the role androgens are thought to have to promote prostate carcinogenesis. Whether this stage difference represents true underlying biological variation in the influence of androgens on early $v s$ aggressive disease will require further study.

Two other findings of inverse associations with non-aggressive disease risk deserve mention. 2-Aminoadipate (as well as pipecolate) is involved in lysine metabolism, and has been found elevated in malignant (T2 and T3) vs adjacent normal prostate tissue and related to earlier disease recurrence (Jung et al, 2013). One of our strongest signals, cyclic AMP, is synthesised from ATP by plasma membrane-associated, hormonally responsive adenylate cyclase, and serves as an intracellular second messenger that mediates several hormones.

As compared with data from the ATBC Study that showed inverse prostate cancer associations with the energy and lipid compounds, including AKG, citrate, inositol-1-phosphate, glycerophospholipids, and fatty acids (Mondul et al, 2015), the present findings portray a very different metabolite-risk profile that features primarily amino acids and peptides. Additional prospective investigations will be needed to interpret the two distinct patterns, but several differences in study designs and populations are likely responsible. Importantly, cases in PLCO were diagnosed within 15 years post-trial following up to four to six prostate screening examinations (i.e., DRE and serum PSA), whereas the cases in ATBC were clinically diagnosed within 20 years of serum collection without systematic PSA and DRE screening. Mean baseline total PSA concentrations of cases were $2 \mathrm{ng} \mathrm{ml}^{-1}$ and $8 \mathrm{ng} \mathrm{ml}^{-1}$ in PLCO and ATBC, respectively, and even the PLCO cases diagnosed with aggressive disease had a mean baseline PSA concentration of only $2 \mathrm{ng} \mathrm{ml}^{-1}$. These and other study differences likely resulted in examination of developmentally distinct metabolic phases of growing prostate adenocarcinomas related to primary tumour size and disease extent.

Time of serum collection and fasting status also differed markedly between the studies; that is, between 0700 hours and 1600 hours in PLCO without regard to time of last meal, vs 0800 hours to 1100 hours after an overnight fast in ATBC. Although the effects of non-fasting status on most of the circulating metabolites 
Table 4. OR and $95 \% \mathrm{Cl}$ from conditional logistic regression of non-aggressive prostate cancer comparision of the 90 th and 10 th percentiles for serum metabolites $(P<0.05)$ sorted by chemical class, sub-pathway, and $P$-value ${ }^{a, b}$

\begin{tabular}{|c|c|c|c|c|c|}
\hline Metabolite & Sub-pathway & OR & $95 \% \mathrm{Cl}$ & $P$-value & $\begin{array}{l}P \text {-value for } \\
\text { chemical class }\end{array}$ \\
\hline \multicolumn{5}{|l|}{ Amino acids and amino acids derivatives } & \multirow[t]{3}{*}{0.69} \\
\hline 2-Aminoadipate & Lysine metabolism & 0.63 & $0.41,0.96$ & 0.0311 & \\
\hline 3-Indoxyl sulfate & Tryptophan metabolism & 0.70 & $0.49,1.00$ & 0.0483 & \\
\hline \multicolumn{5}{|l|}{ Cofactors and vitamins } & \multirow[t]{3}{*}{0.18} \\
\hline Alpha-CEHC sulfate & Tocopherol metabolism & 0.68 & $0.49,0.95$ & 0.0242 & \\
\hline Alpha-tocopherol & Tocopherol metabolism & 0.66 & $0.45,0.96$ & 0.0278 & \\
\hline \multicolumn{5}{|l|}{ Lipids } & \multirow[t]{11}{*}{0.32} \\
\hline 1-Palmitoleoyl-2-linoleoyl-GPC (16:1/18:2) & Phospholipid metabolism & 0.58 & $0.40,0.86$ & 0.0060 & \\
\hline 1-Palmitoyl-2-linolenoyl-GPC (16:0/18:3) & Phospholipid metabolism & 1.62 & $1.05,2.49$ & 0.0293 & \\
\hline 1-Linoleoyl-2-arachidonoyl-GPC (18:2/20:4n6) & Phospholipid metabolism & 1.50 & $1.04,2.16$ & 0.0303 & \\
\hline Taurocholate & Primary bile acid metabolism & 0.60 & $0.40,0.88$ & 0.0094 & \\
\hline 17Alpha-hydroxypregnenolone sulfate & Steroid & 0.70 & $0.51,0.97$ & 0.0303 & \\
\hline 4-Androsten-3beta,17beta-diol disulfate & Steroid & 0.72 & $0.52,0.99$ & 0.0431 & \\
\hline 4-Androsten-3alpha,17alpha-diol monosulfate & Steroid & 0.68 & $0.47,0.99$ & 0.0445 & \\
\hline 1-(1-Enyl-stearoyl)-2-arachidonoyl-GPE (P-18:0/20:4) & Plasmalogen & 1.49 & $1.06,2.10$ & 0.0229 & \\
\hline 2-Hydroxyadipate & Fatty acid, dicarboxylate & 0.66 & $0.45,0.96$ & 0.028 & \\
\hline 2-Stearoyl-GPE (18:0) & Lysolipid & 0.67 & $0.46,0.97$ & 0.0347 & \\
\hline \multicolumn{5}{|l|}{ Nucleotide } & \multirow[t]{2}{*}{0.73} \\
\hline Adenosine $3^{\prime}, 5^{\prime}$-cyclic monophosphate & Purine metabolism, adenine containing & 0.56 & $0.34,0.92$ & 0.0220 & \\
\hline \multicolumn{5}{|l|}{ Peptides } & \multirow[t]{4}{*}{0.29} \\
\hline Threonylphenylalanine & Dipeptide & 1.47 & $1.05,2.06$ & 0.0256 & \\
\hline Gamma-glutamylphenylalanine & Gamma-glutamyl amino acid & 0.65 & $0.44,0.96$ & 0.0315 & \\
\hline Gamma-glutamylglutamine & Gamma-glutamyl amino acid & 1.41 & $1.03,1.94$ & 0.0339 & \\
\hline
\end{tabular}

Table 5. GSA for sub-pathway of serum metabolites and prostate cancer $(P<0.05)$

\begin{tabular}{|c|c|c|}
\hline Sub-pathway & $\begin{array}{c}\text { No. of } \\
\text { contributing } \\
\text { metabolites }\end{array}$ & $\begin{array}{l}P \text {-value } \\
\text { from } \\
\text { GSA }\end{array}$ \\
\hline \multicolumn{3}{|l|}{ Overall prostate cancer } \\
\hline Fatty acid, branched & 2 & 0.016 \\
\hline Tocopherol metabolism & 6 & 0.017 \\
\hline Medium-chain fatty acid & 7 & 0.032 \\
\hline \multicolumn{3}{|l|}{ Aggressive prostate cancer } \\
\hline Fatty acid, branched & 2 & 0.015 \\
\hline Tryptophan metabolism & 20 & 0.037 \\
\hline Urea cycle; arginine and proline metabolism & 17 & 0.046 \\
\hline \multicolumn{3}{|l|}{ Non-aggressive prostate cancer } \\
\hline Tocopherol metabolism & 6 & 0.014 \\
\hline Primary bile acid metabolism & 10 & 0.021 \\
\hline \multicolumn{3}{|l|}{ Overall prostate cancer in Caucasians } \\
\hline Tocopherol metabolism & 6 & 0.007 \\
\hline Fatty acid, branched & 2 & 0.009 \\
\hline Medium-chain fatty acid & 7 & 0.019 \\
\hline
\end{tabular}

we examined have not been rigorously evaluated, some previous studies indicate minimal changes in PSA (Tuncel et al, 2005), lipids (Langsted et al, 2008; Mora et al, 2008), and amino acids such as homocysteine (Fokkema et al, 2003), and one report suggests that fasting status is not an important source of variability in measurements of over 200 metabolites (Townsend et al, 2016). The different populations, US vs Finland, as well as the fact that ATBC included only smokers of at least five cigarettes per day at study entry may also have influenced the divergent findings.

The major strengths of this investigation include use of serum samples that were collected up to two decades prior to prostate cancer diagnosis and good laboratory reproducibility for several hundred metabolites. Our sample size was moderate, albeit the largest to date for a prospective study of the circulating metabolome and risk of prostate cancer. The impact of the PLCO prostate cancer screening on the stages of cases diagnosed and the non-fasting serologic status may have limited the robustness and sensitivity of replicating the previous ATBC findings. In addition, although we could not rule out the possibility of unmeasured confounding factors explaining some of the present findings, including some related to selection of trial post-screening cases, the materially unchanged results from sensitivity analyses that adjusted for several potential risk factors argues against such biases.

In conclusion, the present study demonstrates a unique metabolomic profile associated with post-screening prostate cancer in the PLCO cohort. The inverse associations for amino acid and peptide metabolites, and positive associations for lipids, contrast with the energy/lipid profile previously reported (Mondul et al, $2014,2015)$. This is likely the result of studying prostate cancer 
cases with serum samples collected at an earlier point in the natural history of the disease due to the highly screened nature of the study population, rather than more clinically advanced, yet still undiagnosed, malignancies. The two distinct metabolite profiles may represent molecular species influencing risk of prostate cancers at different points in their development, including early initiating or tumour promoting metabolic states. Whether the inverse association with pGLU is related to a role for thyrotropin status of early prostate cancer will require further study. The metabolomic profiles identified to date should be re-examined in additional prospective analyses of prostate cancer in larger studies and consortia.

\section{ACKNOWLEDGEMENTS}

This work was supported by the Intramural Research Program of the Division of Cancer Epidemiology and Genetics, National Cancer Institute, NIH (Z01-CP010119, ZIA-CP010152-11). We thank Drs Christine Berg and Philip Prorok, Division of Cancer Prevention, NCI, the screening centre investigators and staff of the PLCO Cancer Screening Trial, Mr Thomas Riley and staff at Information Management Services, Inc., and Ms Barbara O’Brien and staff at Westat, Inc. for their contributions to the PLCO and the study participants for donating their time and making this study possible.

\section{CONFLICT OF INTEREST}

The authors declare no conflict of interest.

\section{DISCLAIMER}

The funders had no role in design or conduct of the study; collection, management, analysis, or interpretation of the data; preparation, review, or approval of the manuscript; or the decision to submit the manuscript for publication. The content of this publication does not necessarily reflect the views or policies of the Department of Health and Human Services nor does mention of trade names, commercial products, or organisation indicate endorsement by the US Government.

\section{REFERENCES}

Aksnes H, Hole K, Arnesen T (2015) Molecular, cellular, and physiological significance of N-terminal acetylation. Int Rev Cell Mol Biol 316: 267-305.

Allott EH, Masko EM, Freedland SJ (2013) Obesity and prostate cancer: weighing the evidence. Eur Urol 63(5): 800-809.

Astorg P (2004) Dietary N-6 and N-3 polyunsaturated fatty acids and prostate cancer risk: a review of epidemiological and experimental evidence. Cancer Causes Control 15(4): 367-386.

Balachandran VP, Cavnar MJ, Zeng S, Bamboat ZM, Ocuin LM, Obaid H, Sorenson EC, Popow R, Ariyan C, Rossi F, Besmer P, Guo T, Antonescu CR, Taguchi T, Yuan J, Wolchok JD, Allison JP, DeMatteo RP (2011) Imatinib potentiates antitumor $\mathrm{T}$ cell responses in gastrointestinal stromal tumor through the inhibition of Ido. Nat Med 17(9): 1094-1100.

Barbieri CE, Baca SC, Lawrence MS, Demichelis F, Blattner M, Theurillat JP, White TA, Stojanov P, Van Allen E, Stransky N, Nickerson E, Chae SS, Boysen G, Auclair D, Onofrio RC, Park K, Kitabayashi N, MacDonald TY, Sheikh K, Vuong T, Guiducci C, Cibulskis K, Sivachenko A, Carter SL, Saksena G, Voet D, Hussain WM, Ramos AH, Winckler W, Redman MC, Ardlie K, Tewari AK, Mosquera JM, Rupp N, Wild PJ, Moch H, Morrissey C, Nelson PS, Kantoff PW, Gabriel SB, Golub TR, Meyerson M, Lander ES, Getz G, Rubin MA, Garraway LA (2012) Exome sequencing identifies recurrent SPOP, FOXA1 and MED12 mutations in prostate cancer. Nat Genet 44(6): 685-689.

Bassett JK, Severi G, Hodge AM, MacInnis RJ, Gibson RA, Hopper JL, English DR, Giles GG (2013) Plasma phospholipid fatty acids, dietary fatty acids and prostate cancer risk. Int J Cancer 133(8): 1882-1891.

Bilek R (2000) TRH-like peptides in prostate gland and other tissues. Physiol Res 49(Suppl 1): S19-S26.

Bilek R, Gkonos PJ, Tavianini MA, Smyth DG, Roos BA (1991) Methods used in the study of TRH-like peptides in rat prostate. J Pharm Biomed Anal 9(10-12): 1185-1189.

Bilek R, Gkonos PJ, Tavianini MA, Smyth DG, Roos BA (1992) The thyrotrophin-releasing hormone (TRH)-like peptides in rat prostate are not formed by expression of the TRH gene but are suppressed by thyroid hormone. J Endocrinol 132(2): 177-184.

Bostwick DG, Burke HB, Djakiew D, Euling S, Ho SM, Landolph J, Morrison H, Sonawane B, Shifflett T, Waters DJ, Timms B (2004) Human prostate cancer risk factors. Cancer 101(10 Suppl): 2371-2490.

Carracedo A, Cantley LC, Pandolfi PP (2013) Cancer metabolism: fatty acid oxidation in the limelight. Nat Rev Cancer 13(4): 227-232.

Carter AL, Abney TO, Lapp DF (1995) Biosynthesis and metabolism of carnitine. J Child Neurol 10(Suppl 2): S3-S7.

Cave Jr. WT (1991) Dietary n-3 (omega-3) polyunsaturated fatty acid effects on animal tumorigenesis. FASEB J 5(8): 2160-2166.

Chan JM, Gann PH, Giovannucci EL (2005) Role of diet in prostate cancer development and progression. J Clin Oncol 23(32): 8152-8160.

Chavarro JE, Stampfer MJ, Li H, Campos H, Kurth T, Ma J (2007) A prospective study of polyunsaturated fatty acid levels in blood and prostate cancer risk. Cancer Epidemiol Biomarkers Prev 16(7): 1364-1370.

Cockle SM, Prater GV, Thetford CR, Hamilton C, Malone PR, Mundy AR (1994) Peptides related to thyrotrophin-releasing hormone (TRH) in human prostate and semen. Biochim Biophys Acta 1227(1-2): 60-66.

Crowe FL, Allen NE, Appleby PN, Overvad K, Aardestrup, Johnsen NF, Tjonneland A, Linseisen J, Kaaks R, Boeing H, Kroger J, Trichopoulou A, Zavitsanou A, Trichopoulos D, Sacerdote C, Palli D, Tumino R, Agnoli C, Kiemeney LA, Bueno-de-Mesquita HB, Chirlaque MD, Ardanaz E, Larranaga N, Quiros JR, Sanchez MJ, Gonzalez CA, Stattin P, Hallmans G, Bingham S, Khaw KT, Rinaldi S, Slimani N, Jenab M, Riboli E, Key TJ (2008) Fatty acid composition of plasma phospholipids and risk of prostate cancer in a case-control analysis nested within the European Prospective Investigation into Cancer and Nutrition. Am J Clin Nutr 88(5): 1353-1363.

Crowe FL, Appleby PN, Travis RC, Barnett M, Brasky TM, Bueno-de-Mesquita HB, Chajes V, Chavarro JE, Chirlaque MD, English DR, Gibson RA, Giles GG, Goodman GE, Henning SM, Kaaks R, King IB, Kolonel LN, Kristal AR, Neuhouser ML, Park SY, Severi G, Siddiq A, Stampfer MJ, Stattin P, Tangen CM, Tjonneland A, Trichopoulos D, Tumino R, Wilkens LR, Key TJ, Allen NE. Endogenous Hormones NBProstate Cancer Collaborative Group (2014) Circulating fatty acids and prostate cancer risk: individual participant meta-analysis of prospective studies. J Natl Cancer Inst 106(9): dju240.

Dehaven CD, Evans AM, Dai H, Lawton KA (2010) Organization of GC/MS and LC/MS metabolomics data into chemical libraries. J Cheminform 2(1): 9.

Eberharter A, Becker PB (2002) Histone acetylation: a switch between repressive and permissive chromatin. Second in review series on chromatin dynamics. EMBO Rep 3(3): 224-229.

Evans AM, DeHaven CD, Barrett T, Mitchell M, Milgram E (2009) Integrated, nontargeted ultrahigh performance liquid chromatography/electrospray ionization tandem mass spectrometry platform for the identification and relative quantification of the small-molecule complement of biological systems. Anal Chem 81(16): 6656-6667.

Ferdinande L, Decaestecker C, Verset L, Mathieu A, Moles Lopez X, Negulescu AM, Van Maerken T, Salmon I, Cuvelier CA, Demetter P (2012) Clinicopathological significance of indoleamine 2,3-dioxygenase 1 expression in colorectal cancer. Br J Cancer 106(1): 141-147.

Fleming ID, Cooper JS, Henson ED, Hutter RVP, Kennedy BJ, Murphy GP, O'Sullivan B, Sobin LH, Yarbro JW (1997) AJCC Cancer Staging Manual. 5th edn, Lippincot-Raven: Philadelphia, PA, USA.

Fokkema MR, Gilissen MF, Van Doormaal JJ, Volmer M, Kema IP, Muskiet FA (2003) Fasting vs nonfasting plasma homocysteine concentrations for diagnosis of hyperhomocysteinemia. Clin Chem 49(5): 818-821.

Gang X, Yang Y, Zhong J, Jiang K, Pan Y, Karnes RJ, Zhang J, Xu W, Wang G, Huang H (2016) P300 acetyltransferase regulates fatty acid synthase 
expression, lipid metabolism and prostate cancer growth. Oncotarget 7(12): 15135-15149.

Gohagan JK, Prorok PC, Hayes RB, Kramer BS, Prostate LC. Ovarian Cancer Screening Trial Project Team (2000) The Prostate, Lung, Colorectal and Ovarian (PLCO) Cancer Screening Trial of the National Cancer Institute: history, organization, and status. Control Clin Trials 21(6 Suppl): 251S-272S.

Harvei S, Bjerve KS, Tretli S, Jellum E, Robsahm TE, Vatten L (1997) Prediagnostic level of fatty acids in serum phospholipids: omega- 3 and omega- 6 fatty acids and the risk of prostate cancer. Int J Cancer 71(4): 545-551.

Hayes RB, Sigurdson A, Moore L, Peters U, Huang WY, Pinsky P, Reding D, Gelmann EP, Rothman N, Pfeiffer RM, Hoover RN, Berg CD, Team PT (2005) Methods for etiologic and early marker investigations in the PLCO trial. Mutat Res 592(1-2): 147-154.

Heinonen OP, Albanes D, Virtamo J, Taylor PR, Huttunen JK, Hartman AM, Haapakoski J, Malila N, Rautalahti M, Ripatti S, Maenpaa H, Teerenhovi L, Koss L, Virolainen M, Edwards BK (1998) Prostate cancer and supplementation with alpha-tocopherol and beta-carotene: incidence and mortality in a controlled trial. J Natl Cancer Inst 90(6): 440-446.

Huber AE, Fraser H, del Rio-Garcia J, Kreil G, Smyth DG (1998) Molecular cloning in the marmoset shows that semenogelin is not the precursor of the TRH-like peptide pGlu-Glu-Pro amide. Biochim Biophys Acta 1387(1-2): 143-152.

Jolliffe I (2005) Principal component analysis. In: Encyclopedia of Statistics in Behavioral Science. Chichester: Wiley, UK.

Jung K, Reszka R, Kamlage B, Bethan B, Stephan C, Lein M, Kristiansen G (2013) Tissue metabolite profiling identifies differentiating and prognostic biomarkers for prostate carcinoma. Int J Cancer 133(12): 2914-2924.

Key TJ, Appleby PN, Travis RC, Albanes D, Alberg AJ, Barricarte A, Black A, Boeing H, Bueno-de-Mesquita HB, Chan JM, Chen C, Cook MB, Donovan JL, Galan P, Gilbert R, Giles GG, Giovannucci E, Goodman GE, Goodman PJ, Gunter MJ, Hamdy FC, Heliovaara M, Helzlsouer KJ, Henderson BE, Hercberg S, Hoffman-Bolton J, Hoover RN, Johansson M, Khaw KT, King IB, Knekt P, Kolonel LN, Le Marchand L, Mannisto S, Martin RM, Meyer HE, Mondul AM, Moy KA, Neal DE, Neuhouser ML, Palli D, Platz EA, Pouchieu C, Rissanen H, Schenk JM, Severi G, Stampfer MJ, Tjonneland A, Touvier M, Trichopoulou A, Weinstein SJ, Ziegler RG, Zhou CK, Allen NE. Endogenous Hormones Nutritional Biomarkers Prostate Cancer Collaborative Group (2015) Carotenoids, retinol, tocopherols, and prostate cancer risk: pooled analysis of 15 studies. Am J Clin Nutr 102(5): 1142-1157.

Kobayashi N, Barnard RJ, Henning SM, Elashoff D, Reddy ST, Cohen P, Leung P, Hong-Gonzalez J, Freedland SJ, Said J, Gui D, Seeram NP, Popoviciu LM, Bagga D, Heber D, Glaspy JA, Aronson WJ (2006) Effect of altering dietary omega-6/omega-3 fatty acid ratios on prostate cancer membrane composition, cyclooxygenase-2, and prostaglandin E2. Clin Cancer Res 12(15): 4662-4670.

Koblish HK, Hansbury MJ, Bowman KJ, Yang G, Neilan CL, Haley PJ, Burn TC, Waeltz P, Sparks RB, Yue EW, Combs AP, Scherle PA, Vaddi K, Fridman JS (2010) Hydroxyamidine inhibitors of indoleamine-2,3dioxygenase potently suppress systemic tryptophan catabolism and the growth of IDO-expressing tumors. Mol Cancer Ther 9(2): 489-498.

Kote-Jarai Z, Olama AA, Giles GG, Severi G, Schleutker J, Weischer M, Campa D, Riboli E, Key T, Gronberg H, Hunter DJ, Kraft P, Thun MJ, Ingles $\mathrm{S}$, Chanock S, Albanes D, Hayes RB, Neal DE, Hamdy FC, Donovan JL, Pharoah P, Schumacher F, Henderson BE, Stanford JL, Ostrander EA, Sorensen KD, Dork T, Andriole G, Dickinson JL, Cybulski C, Lubinski J, Spurdle A, Clements JA, Chambers S, Aitken J, Gardiner RA, Thibodeau SN, Schaid D, John EM, Maier C, Vogel W, Cooney KA, Park JY, Cannon-Albright L, Brenner H, Habuchi T, Zhang HW, Lu YJ, Kaneva R, Muir K, Benlloch S, Leongamornlert DA, Saunders EJ, Tymrakiewicz M, Mahmud N, Guy M, O’Brien LT, Wilkinson RA, Hall AL, Sawyer EJ, Dadaev T, Morrison J, Dearnaley DP, Horwich A, Huddart RA, Khoo VS, Parker CC, Van As N, Woodhouse CJ, Thompson A, Christmas T, Ogden C, Cooper CS, Lophatonanon A, Southey MC, Hopper JL, English DR, Wahlfors T, Tammela TL, Klarskov P, Nordestgaard BG, Roder MA, Tybjaerg-Hansen A, Bojesen SE, Travis R, Canzian F, Kaaks R, Wiklund F, Aly M, Lindstrom S, Diver WR, Gapstur S, Stern MC, Corral R, Virtamo J, Cox A, Haiman CA, Le Marchand L, Fitzgerald L, Kolb S, Kwon EM, Karyadi DM, Orntoft TF, Borre M, Meyer A, Serth J, Yeager M, Berndt SI, Marthick JR, Patterson B, Wokolorczyk D, Batra J, Lose F, McDonnell SK, Joshi AD, Shahabi A,
Rinckleb AE, Ray A, Sellers TA, Lin HY, Stephenson RA, Farnham J, Muller H, Rothenbacher D, Tsuchiya N, Narita S, Cao GW, Slavov C, Mitev V, Easton DF, Eeles RA. UK Genetic Prostate Cancer Study Collaborators/British Association of Urological Surgeons' Section of OncologyUK ProtecT Study Collaborators, The Australian Prostate Cancer BioResourcePRACTICAL Consortium (2011) Seven prostate cancer susceptibility loci identified by a multi-stage genome-wide association study. Nat Genet 43(8): 785-791.

Kuemmerle NB, Rysman E, Lombardo PS, Flanagan AJ, Lipe BC, Wells WA, Pettus JR, Froehlich HM, Memoli VA, Morganelli PM, Swinnen JV, Timmerman LA, Chaychi L, Fricano CJ, Eisenberg BL, Coleman WB, Kinlaw WB (2011) Lipoprotein lipase links dietary fat to solid tumor cell proliferation. Mol Cancer Ther 10(3): 427-436.

Langsted A, Freiberg JJ, Nordestgaard BG (2008) Fasting and nonfasting lipid levels: influence of normal food intake on lipids, lipoproteins, apolipoproteins, and cardiovascular risk prediction. Circulation 118(20): 2047-2056.

Larsson SC, Kumlin M, Ingelman-Sundberg M, Wolk A (2004) Dietary long-chain n-3 fatty acids for the prevention of cancer: a review of potential mechanisms. Am J Clin Nutr 79(6): 935-945.

Liu J, Lu G, Tang F, Liu Y, Cui G (2009) Localization of indoleamine 2,3-dioxygenase in human esophageal squamous cell carcinomas. Virchows Arch 455(5): 441-448.

Maher P (2005) The effects of stress and aging on glutathione metabolism. Ageing Res Rev 4(2): 288-314.

Mannisto S, Pietinen P, Virtanen MJ, Salminen I, Albanes D, Giovannucci E, Virtamo J (2003) Fatty acids and risk of prostate cancer in a nested case-control study in male smokers. Cancer Epidemiol Biomarkers Prev 12(12): 1422-1428.

Maran RR, Ravichandran K, Arunakaran J (2001) Prostate-thyroid axis: prostatic TRH is one of the stimulators of thyroid hormone. Endocr Res 27(1-2): 143-152.

Mondul AM, Moore SC, Weinstein SJ, Karoly ED, Sampson JN, Albanes D (2015) Metabolomic analysis of prostate cancer risk in a prospective cohort: the alpha-tocolpherol, beta-carotene cancer prevention (ATBC) study. Int J Cancer 137(9): 2124-2132.

Mondul AM, Moore SC, Weinstein SJ, Mannisto S, Sampson JN, Albanes D (2014) 1-stearoylglycerol is associated with risk of prostate cancer: results from serum metabolomic profiling. Metabolomics 10(5): 1036-1041.

Mora S, Rifai N, Buring JE, Ridker PM (2008) Fasting compared with nonfasting lipids and apolipoproteins for predicting incident cardiovascular events. Circulation 118(10): 993-1001.

Nomura DK, Lombardi DP, Chang JW, Niessen S, Ward AM, Long JZ, Hoover HH, Cravatt BF (2011) Monoacylglycerol lipase exerts dual control over endocannabinoid and fatty acid pathways to support prostate cancer. Chem Biol 18(7): 846-856.

Nomura DK, Long JZ, Niessen S, Hoover HS, Ng SW, Cravatt BF (2010) Monoacylglycerol lipase regulates a fatty acid network that promotes cancer pathogenesis. Cell 140(1): 49-61.

Norrish AE, Skeaff CM, Arribas GL, Sharpe SJ, Jackson RT (1999) Prostate cancer risk and consumption of fish oils: a dietary biomarker-based casecontrol study. Br J Cancer 81(7): 1238-1242.

Prendergast GC, Smith C, Thomas S, Mandik-Nayak L, Laury-Kleintop L, Metz R, Muller AJ (2014) Indoleamine 2,3-dioxygenase pathways of pathogenic inflammation and immune escape in cancer. Cancer Immunol Immunother 63(7): 721-735.

Prorok PC, Andriole GL, Bresalier RS, Buys SS, Chia D, Crawford ED, Fogel R, Gelmann EP, Gilbert F, Hasson MA, Hayes RB, Johnson CC, Mandel JS, Oberman A, O'Brien B, Oken MM, Rafla S, Reding D, Rutt W, Weissfeld JL, Yokochi L, Gohagan JK, Prostate LC. Ovarian Cancer Screening Trial Project Team (2000) Design of the Prostate, Lung, Colorectal and Ovarian (PLCO) Cancer Screening Trial. Control Clin Trials 21(6 Suppl): 273S-309S.

Rose DP (1997) Effects of dietary fatty acids on breast and prostate cancers: evidence from in vitro experiments and animal studies. Am J Clin Nutr 66(6 Suppl): 1513S-1522S.

Santhanam S, Alvarado DM, Ciorba MA (2016) Therapeutic targeting of inflammation and tryptophan metabolism in colon and gastrointestinal cancer. Transl Res 167(1): 67-79.

Subramanian A, Tamayo P, Mootha VK, Mukherjee S, Ebert BL, Gillette MA, Paulovich A, Pomeroy SL, Golub TR, Lander ES, Mesirov JP (2005) Gene set enrichment analysis: a knowledge-based approach for interpreting genome-wide expression profiles. Proc Natl Acad Sci USA 102(43): 15545-15550. 
Torre LA, Bray F, Siegel RL, Ferlay J, Lortet-Tieulent J, Jemal A (2015) Global cancer statistics, 2012. CA Cancer J Clin 65(2): 87-108.

Townsend MK, Bao Y, Poole EM, Bertrand KA, Kraft P, Wolpin BM, Clish CB, Tworoger SS (2016) Impact of pre-analytic blood sample collection factors on metabolomics. Cancer Epidemiol Biomarkers Prev 25(5): 823-829.

Tuncel A, Aksut H, Agras K, Tekdogan U, Ener K, Atan A (2005) Is serum prostate-specific antigen level affected by fasting and nonfasting? Urology 66(1): 105-107.

Uyttenhove C, Pilotte L, Theate I, Stroobant V, Colau D, Parmentier N, Boon T, Van den Eynde BJ (2003) Evidence for a tumoral immune resistance mechanism based on tryptophan degradation by indoleamine 2,3-dioxygenase. Nat Med 9(10): 1269-1274.

Witkiewicz A, Williams TK, Cozzitorto J, Durkan B, Showalter SL, Yeo CJ, Brody JR (2008) Expression of indoleamine 2,3-dioxygenase in metastatic pancreatic ductal adenocarcinoma recruits regulatory $\mathrm{T}$ cells to avoid immune detection. J Am Coll Surg 206(5): 849-854.

Wolk A (2005) Diet, lifestyle and risk of prostate cancer. Acta Oncol 44(3): 277-281.

Wu G, Fang YZ, Yang S, Lupton JR, Turner ND (2004) Glutathione metabolism and its implications for health. J Nutr 134(3): 489-492.
Wu X, Daniels G, Lee P, Monaco ME (2014) Lipid metabolism in prostate cancer. Am J Clin Exp Urol 2(2): 111-120.

Zhang G, Liu WL, Zhang L, Wang JY, Kuang MH, Liu P, Lin YH, Dai SQ, Du J (2011a) Involvement of indoleamine 2,3-dioxygenase in impairing tumor-infiltrating CD8 T-cell functions in esophageal squamous cell carcinoma. Clin Dev Immunol 2011: 384726.

Zhang H, Forman HJ, Choi J (2005) Gamma-glutamyl transpeptidase in glutathione biosynthesis. Methods Enzymol 401: 468-483.

Zhang R, Li H, Yu J, Zhao J, Wang X, Wang G, Yao Z, Wei F, Xue Q, Ren X (2011b) Immunoactivative role of indoleamine 2,3dioxygenase in gastric cancer cells in vitro. Mol Med Rep 4(1): 169-173.

Zhang R, Liu H, Li F, Li H, Yu J, Ren X (2013) The correlation between the subsets of tumor infiltrating memory $\mathrm{T}$ cells and the expression of indoleamine 2,3-dioxygenase in gastric cancer. Dig Dis Sci 58(12): 3494-3502.

(c) (i) (2) (2) This work is licensed under the Creative Commons BY NC sa Attribution-Non-Commercial-Share Alike 4.0 International License. To view a copy of this license, visit http:// creativecommons.org/licenses/by-nc-sa/4.0/

Supplementary Information accompanies this paper on British Journal of Cancer website (http://www.nature.com/bjc) 